\title{
Learned Societies and Academies in Early Times
}

\section{Edward Conradi Ph. D.}

To cite this article: Edward Conradi Ph. D. (1905) Learned Societies and Academies in Early Times, The Pedagogical Seminary, 12:4, 384-426, DOI: 10.1080/08919402.1905.10534668

To link to this article: http://dx.doi.org/10.1080/08919402.1905.10534668

曲 Published online: 30 Aug 2012.

Submit your article to this journal $\pi$

LII Article views: 8

Q View related articles $₫$

Citing articles: 1 View citing articles 

TIMES. ${ }^{1}$

By Edward Conradi, Ph. D., Principal Normal and Industrial School, St. Petersburg, Fla.

\section{INTRODUCTION.}

"The history of Italian academies, written not according to their exterior but according to their secret tendencies, would not only be an interesting chapter in culture history, but would open deep vistas into the political conditions of the people and the country." These words of Reumont, written in 1857 , would suffer neither in truth nor in force if they included other than Italian academies, and it can only be regretted that Reumont's suggestion and example did not bring forth earlier results.

The history of learned societies has not yet been written and it is not here the intention to perform that task. It is rather the aim, (I) to give, as far as possible, an outline sketch of the development of such societies from early times with special emphasis on the period covering the Renaissance and the Reformation, and (2) to suggest the influence they have bad on the development of thought with special reference to educational movements. Very little has been done in this field in English. The Germans with their keen historical sense, have made a beginning, but only a beginuing. 'To what extent a continuous history can be written the future only can tell. From 529 A. D., when Justiuian suppressed the Platonic academies, for about eight centuries little or nothing is known of their existence. Whether during this period there were any societies of learning is not yet definitely known, and may never be known, since their very existence depended upon the thoroughness of the secrecy they were able to maintain. Further research in this field, however, may bring forth valuable results. From the time of Plato till 529 A. D., and from the time

1 This study was nearly completed while the writer was an honorary fellow in Clark University, and he takes pleasure in acknowledging his great indebtedness to Dr. Wm. H. Burnham for suggesting the study and for valuable suggestions and references to literature; to Pres. G. Stanley Hall for suggestions and criticisms and for the use of his private library; and to Dr. L. N. Wilson for invaluable aid in securing rare books. 
of the Renaissance till the present time-though much remains dark-the history of academies is better known and forms a valuable part of the culture history of those periods. Our histories of education, however, ignore the subject almost completely.

It is strange that the history of learned societies, especially of that period covering the dark ages, has not been studied earlier with great thoroughness. For it is now known that during the $15^{\text {th, }}$ I6th, and $17^{\text {th }}$ centuries these societies, usually secret, were the places where the pioneers of free thought and of science, such as Galileo, Bruno, Andreae, Comenius, Leibniz and a host of others could work out and exchange their views unmolested; and it may have been such societies which determined to a large extent the time of the Renaissance, and which, even while under the ban, may have carried through the dark ages the lamp of learning at which Dante and Petrarch lit their torch-Dante and Petrarch, "the two great pillars which encase the door through which we enter the great revival of learning."

As to the question when did learned societies begin to exist, very little definite can be said. One might almost as well ask when did man begin to think? Schleiermacher thinks that in the very need of science there is the need of the scientific society. He says the very impulse toward knowledge leads necessarily to communication and community of all sorts, and that the public institutions which this requires arise absolutely voluntarily and need the state only in their further development, but only to be protected and favored by it.

Early Greek, Egyptian and Arabian Academies.

The Greek Academies. The word 'academy' immediately reminds one of Plato, and the name undoubtedly comes from the school which he founded. It is well known that this academy existed for hundreds of years, and when we, after the dark ages, again meet the name in Italy it refers to associations of scholars who devoted themselves chiefly to the study of Plato, and who in their aims and in their forms had a surprising similarity with the aims and forms of the Platonic as well as the Neo-Platonic academies. However, such associations of scholars were known in Greece before the time of Plato.

Philosophers are now convinced that early Greek philosophy developed in religious schools similar to those of Plato and Aristotle. Diels says it seems to him certain that Thales stood in the midst of a circle of eminent pupils who wanted to make practical and scientific use of mathematico-natural science. Though Thales left no writings he was known to, and attacked by, later thinkers, and according to ancient tradition this school 
had a direct succession from Thales to Anaximenes (about 600500 B. C.).

That the Pythagorean and the Eleatic schools had a close organization is well known, and Diels says that it is certain that the strict organization of these schools has influenced their great achievements just as the common work of the academy has influenced the Platonic-Aristotelian system.

A very dense veil shrouds the atomistic school. Not only is tradition as to this important school meagre, but its valuable literature has been destroyed almost to the last line. However, the writings of Leucippus, the founder of materialism, have so much similarity with those of Democritus that they might be fused with them, a similarity which points to a close contact as it is possible only in a well organized school. Moreover, Democritus was a man who, according to Aristotle, had thought about everything. The catalogue of his writings as well as the few fragments of his works which have been preserved show that he was active in all the domains of knowledge: Cosmology, Anthropology, Psychology, Logic, Mathematics, Astronomy, Poetry, Grammar, Ethics, etc. The field of activity is indeed so wide that we must assume that some of these writings are spurious or that there was a masterful organization which collected this wealth of material and worked it over scientifically. This encyclopedia gave a model for Aristotle's all comprehensive work which he could carry out only with the faithful co-operation of his friends and pupils.

Diels says of this school: "Soon after the time of Alexander this beautiful structure was a ruin. Only a few pillars have, without severe mutilation, been built into the Gardenhouse of Epicurus. But this scanty remnant of that former glory, as it is manifested by the letters of Epicurus which were dug up by Pierre Gassendi, has given the foundation upon which the magnificent structure of modern science has been erected."

Information about the inner organization of these schools is very meagre, and, since knowled ge as to the subjects and methods of instruction is scarce even in regard to the Platonic and the Aristotelian schools, we can scarcely hope that tradition will give us further light as to the older schools. That the Peripatetic, the Stoic, the Epicurean, and the Platonic philosophies were handed down by organized schools, is well known and yet we know little of the inner workings of even the Platonic and Aristotelian schools. Plato founded the academy and provided it not only with a meeting place but with sufficient revenue for its support. The estate he bequeathed to the muses, and therefore, when in 529 the Greek gods were dethroned by Justinian, the property reverted to the state. The work of the 
academy was directed by a leader who was elected by a majority vote of the members. Not only was philosophy studied, but zoölogy, botany, geography, mathematics, and astronomy, were cultivated.

Like the academy, the Peripatetics also had a garden and halls, but in addition had some residences for the members to live in. Wilamowitz says the real estate and mostly the slaves, house furnishings and books belonged to the leader and he transferred the real estate by will to his successors. In case more than one heir was designated, they elected from their midst the leader. Though by this election the other members gave up all claim to leadership, yet in such case the school was divided into two groups, members and pupils. The pupils could participate in the cult, feastmeals, use of books, etc., and could attend lectures, but they could fill only the lower offices of the school.

There was no revenue producing capital. The pupils paid certain monthly dues, the members not. The financial affairs were attended to by the leader whose private accounts were not separated from that of the school.

Besides a leader the school had a number of minor officers such as the monthly Headship, a Supervisor of Sacred Rites, and a Curator for the worship of the Muses. The customary monthly Headship supervised the conduct of the members and collected nine obols from each member to provide for the monthly feast.

Never, in the history of the world, has the sublimity of striving after scientific truth been felt more deeply and more keenly than with the Platonists and the early Greek thinkers. It was the true religion for them. Science presents to them "the question of life and death before which everything earthly to which one may attach his love must vanish." Aristotle says, only that soul can raise itself to the "ethereal habitations of the gods" who has reached by true scientific endeavor the highest goal of man. Usener says that, excepting medicine, mathematics, astronomy, mechanics, and grammer, the achievements of Plato and Aristotle and their immediate pupils in the domains of mental and natural science stood unequalled till recent and partly till quite recent times.

The influence of these achievements on later thought is so well known that it needs no furthur mention here; the important thing for us to note here is that these giant attainments must be ascribed to academies rather than to schools as we understand the term. Usener says it is wrong to consider these schools (Plato's and Aristotle's) as a number of pupils flocking around a master. They were organizations for research as well as for learning and listening. Their membership included 
the whole series from the youth first approaching scientific studies to the independent investigator. And Zeller says: These Greek schools were not only unions of teachers and pupils, but they were at the same time organizations of scientists. They had the character both of a school and an academy. The organization had a leader who directed the work but it occasionally happened that some of the older men who remained in the society after their student years surpassed the leader in scientific attainment and in fame.

It may, indeed, not be far amiss to say that the greatest progress in the extension of human knowledge has been made by those seekers after - often martyrs for - truth, who scorn the restrictions of sect or school and who recognize no criterion but truth itself. Those great universities of to-day who set the milestones in the domain of science can do so only because they offer a free field of activity for the best scholars of their time - because they are built on the fundamental principle of all academies, "Freie Forschung und Freie Lehre," the very principle which has made them, and will ever make them, the leaders of thought.

The Alexandrian Academy. The battle of Chaeronea, which doomed the freedom of the Greek states, also gave the deathblow to free and independent thinking in Greece. About the same time the Ptolemies in Egypt saw that to save their own sovereignty they had to contrapose the culture of the Greeks against the dead wisdom of their native scholars and priests. They founded at Alexandria a great museum and two magnificent libraries and invited scholars to come there to study. Thus it happens that about three centuries before our era, on the banks of the Nile, we find the beginning of probably the greatest academy the world has ever known, making Alexandria the intellectual centre of the world. It was here at Alexandria, according to Baer, in the museum, where for the first time men from all parts of the then civilized world assembled with no other purpose than to extend the domain of human knowledge according to their own desire and inclination, and where the house of the Ptolemies, with lavish hands, furnished the means so that the scholars were not troubled with any cares for the necessaries of life. There were similar intellectual activities at Pergamon, Antioch in Syria, and other places, but all were completely overshadowed by Alexandria.

Baer says that here in Alexandria, where the ideas of the Egyptians, the Greeks, and the Jews clashed, science was born. In Alexandria we find the first physical apparatus and the first physical experiments, and here, by an examination of the human body, a basis was laid for medicine that lasted till the beginning of the $16 \mathrm{th}$ century. Here philosophy and history 
of literature were born and mathematics was cultivated by Euclid. Here the first attempt was made to measure degrees and the first catalogue of the stars was constructed; also the astronomical system of Ptolemy was developed which prevailed for over a thousand years. Strabo here also collected much of his material for his geography. And, furthermore, how much more of ancient culture would have been lost had not the manuscripts been collected here and multiplied by numberless duplicates by the copyists? Baer says the influence of this academy, which was such not in name but in reality, is immense. He says it is here where science first energed out of its poetic form, and adds: "We, after two thousand years in this place and at this time, on the banks of the Neva, are under the influence of Alexandrian astronomy."

The intellectual activity at Alexandria extended over nearly $\mathrm{I}, \mathrm{O}$ - years. But this very long period falls into two divisions. The first period is characterized by its literary and scientific activity and lasts from about $306 \mathrm{~B}$. C. to about $30 \mathrm{~B}$. C. It was an attempt to continue and develop under new conditions the old Hellenic culture. The second period, from $30 \mathrm{~B}$. C. to $640 \mathrm{~A}$. D., is a period of philosophy and is largely determined by Jewish elements. It was in this period in the early centuries of the Christian era, when Greek philosophy and religion met Oriental philosophy and religion, that Neo-Platonism was born. It was in the early years of the third century that Ammonius Saccas inspired his pupil Plotinus who, in turn, about $244 \mathrm{~A}$. D., founded a school of philosophy in Rome. This school was followed by others. These Neo-Platonic schools, however, were founded especially for the propagation and development of certain doctrines, and do not exactly correspond to what we today would call a learned society, yet they were probably the forerunners of the later Italian Platonic Academies and the carriers of Platonism and that Socratic elenchus which finally broke through the darkness during the middle ages and ushered in the dawn of day. It is important to note that Platonism and Neo-Platonism were, in the words of Harnack, the source from which in the age of the Renaissance and in the following two centuries, empiric science developed in opposition to the rationalistic dogmatism which disregards experience. Magic, astrology, alchemy, subjects which were of the keenest common interest to the later natural philosophers of Europe, and which gave an effective impulse to the observation of nature, and consequently to natural science, were closely connected with Neo-Platonism.

Arabian Academies. During the centuries when Platonism and Neo-Platonism were suppressed and seemingly forgotten in Roman Christendom, it was the Arabians who carried forward 
this heritage. The schools founded by Harun-al-Raschid and al Mamun at Bagdad, Kufa, Bassora, Bochara and other places, about the time Charles the Great was gathering the wisest men of his time about his throne, were schools rather than' academies, but it is well known that the above named califs made great efforts to get men of learning to their courts. Mamun, for instance, offered a great sum of money and eternal peace to the Greek Emperor Theophilus if he would give for a time the services of the famous mathematician Leo; an offer which the Emperor rejected in order that science might remain a preference of the Greeks. And Baer says that the famous Orientalist Frähn told him that in the roth century there existed a society in Bassora called Ichwan-al-safa (Brothers of Purity) which exactly resembled our academies of to-day. They even published proceedings (Sammlung Abhandlungen) in which are treated philosophical, physical, mathematical, and theological subjects, and which are preserved to the present day. There was so much liberality (Freisinnigkeit) in these proceedings that later an auto-da-fé was held over them in Bagdad.

The most famous Arabian academy, however, was that at Cordova in Spain. It was so famous in its time that scholars flocked there from all parts of the then civilized world. They came from France, Germany, Italy, England, Greece, from North Africa, Syria, Arabia, Persia, and even from distant India to study there or to live for science and poetry which were flourishing under Hakem II. This prince even sent representatives to the larger cities of Africa, Egypt, Syria, Arabia and Persia to either buy or copy the best works. In this way he gathered a library variously estimated at from 400,000 to 600 ,ooo manuscripts. The catalogue, according to authentic sources, contained 44 volumes.

There were other schools in Spain, but Cordova was by far the most famous. It was an academy on the Alexandrian type. Hakem II demanded nothing of his protégés but to complete the researches and other works they had begun or had promised, and did everything in his power to secure for them the means and the leisure, and even gave up his palaces to them. Moreover, Aschbach reports a society of 40 scholars and poets who during the winter regularly met at the house of a priest in Toledo for scientific work. This is very much like the beginnings of the later Royal Societies of France and England.

Among the Arabian philosophers, Averroes (died 1 I 98 ), whose writings were known to the entire cultured Occident, was probably the greatest. His doctrines, which found acceptance among the heretics, were considered heretical by both Moslem and Christian. The literature of the Averroists is mostly destroyed, as is the case with all parties that were persecuted by 
the church, but from the attitude of their opponents it seems that they were convinced that the Averroists formed a well organized society. Voigt says: "It seems that the Averroists were a kind of secret society which held together by a secret understanding and pass words (Stichworte), and which, by its ramifications and its position beside the church reminds one of Free Masonry." (Cited by Keller.)

It is important to note that Dante and Petrarch grew up in this atmosphere, and what these two men, especially the former, mean to the world need not be restated here. On March roth, 1302, Dante was condemned to be burned at the stake, and from that time till his death he was a wanderer in the wide world and not only tasted the bitter and the sweet that always come to the great champions of individuality and of freedom, but lived face to face with the philosophy of his time. With admirable independence he brushed aside the traditions and the language of the church by denying the church the right to use force in matters of religion, and by writing the master creation of his genius in the language of his people, thus demonstrating to the world that Greece and Rome had not exhausted language and showing the possibilities that lie hidden in the vernacular of common folk.

Two years after Dante had gone into exile, Petrarch was born. He was a student of philosophy, and through the study of the Greek language became a warm admirer of Plato. $\mathrm{He}$ also was finally accused of being a magician and a heretic and was even suspected of being a leader among the Averroists. In his old age, however, he was converted to the Roman Catholic faith and devoted his last years to defending it. Among the men whom Petrarch espeeially tried to convert to the faith was Ludovico Marsilio (died I393). This man was at the head of a society sometimes called Academia di San Spirito, to which Coluccio Salutatis and Niccolo Niccolis belonged. It was Niccolis who persuaded the famous Platonist, Manuel Chrysoloras, a pupil of Plethon, to stop for a while at Florence and to thus become the teacher of many men who belonged to this society. This academy is known in history simply as a literary society, yet it had among its members poets, philosophers, scholars and artists. Moreover, it seems that Platonism was dominant here as in later Platonic academies. Here, Keller says, we meet the first traces of the close working together of science and the arts, which has given the real stamp to the great period of the Renaissance.

ITALIAN ACADEMIES.

What became of the Platonic academies from the time Justinian suppressed them, in $5^{29}$ A. D., until they again began to 
flourish in Italy about 800 years later, is not known. Keller thinks it is altogether improbable that these academies which had braved all storms and all changes for a thousand years should be destroyed with one stroke. He says that doubtless these experienced men ceased to work in the forbidden forms, but that it would be remarkable if they could not have found secret means to follow their ideals in legally permitted institutions until such a time when the academies could again appear on the surface.

Keller says the word "academy" appears in Italy as early as 1439 in connection with Bessarion's name, but that that is no evidence that no such organizations existed before that time. As we shall see, for instance, the pupils and followers of Plethon formed a kind of society or academy and the church was issuing decrees against similar societies more than 150 years earlier. The history of these Italian academies is difficult to follow because they are secret societies. Their constitutions, their sym. bolism, their signs, their list of members, their highest religious convictions were withheld from the public. It was at the time often said in Italy that the Platonists live in their academies, "like the Greeks formerly in their Trojan horse." This secrecy, made necessary by the severe persecution of the church, made it almost as difficult for the historian of their time as it is for the later historians to study their history.

That there were societies as early as the I $3^{\text {th }}$ century is shown by the decrees of the church councils and of the Roman Curia. The Council at Valence under Innocent IV, in 1248 , forbade, under penalty of excommunication, the societies which were held together by oaths and pledges. This seems to have failed to produce the desired effect, and so in 1282 at another conncil at Avignon even stricter regulations were passed. The council at Avignon of 1327 again emphasized these regulations and specified more in detail the character of these societies. According to this decree there were forbidden societies in the church which had their chief, their feastmeals, mutual pledges of brotherly assistance, signs and symbols, and a society uniform. The fact that these decrees were expressly directed against societies which had existed since ancient times, shows that this is probably an old struggle, that the church was dealing here not with local societies but with a strong and wide spread organization.

Keller is undoubtedly right when he says that the banishment of the Greek gods did not mean the extinction of the fire in the souls of the Platonists. If it be true that they continued their activity in other legal organizations it is probable that they entered the inner circles of labor guilds, since mathematics and geometry, which were of so much importance to some of the 
most important trades, were assiduously cultivated by the academies, and since later in the middle ages we find many points of similarity between the academies and labor guilds, whose inner circles were often called academy. Furthermore, it is held that Christianity in its early years found its first and strongest foothold among labor guilds, since their idea of brotherhood had much the same in spirit as that represented by the Christians. Ward says that history shows that Christians planted into, and for the first two hundred years derived their sustenance, support, legalization, and economical life from labor unions of the ancient world. He says the word ecclesia and diocese came into the church through the labor unions, they applied this word to their houses of worship. $\mathrm{He}$ says the prechristian trade unions possessed their temples as common property around which were the graveyard, the grove, and many fixtures for meetings, discussions, entertainments and comforts of every kind, and that these temples gradually developed into churches.

We know also the close relationship between Neo-Platonism and Christianity, and that heretical sects in later years often maintained themselves in labor guilds; therefore, at least the possibility exists that Platonic ideas were carried through the dark ages by these guilds. Moreover, considering the pertinacity with which not only the Italian academies maintained themselves during times of persecution, but also how the heretics maintained themselves secretly and yet unitedly even from the early Christian centuries up to the time when intelligent people were permitted to call " heresy" enlightenment, and how easy it was for Platonic ideas to find enthusiastic supporters in Italy and otherwheres, it is not entirely a cry in the dark to say that these academies have had a continuous existence in some form or other from the time of Plato till now.

After the suppression of the Platonic academies, the church riveted its dogma firmer and firmer and freedom of thought seemed to be doomed. The church fought against all heathen philosophy, but finding it necessary to justify its dogma by means of reason, she finally used the Aristotelian logic to accomplish her ends. This scholastic dogmatism degenerated into such dry formalism that no independent spirit could live in its shackles. But how live outside of them so long as the church was with blighting hand withering every sign of verdure it could find outside of its pale? Probably best by replacing one authority by another; by replacing the degenerated church Aristotelianism by the ever living Platonic passion for truth, a passion which has appealed to all great minds in all ages. Schultze says the great struggle in philosophy for several thousand years has been between Aristotle and Plato; " as one 
of these stars sinks' below the horizon and the other rises, a new era in philosophy begins." The important thing in this return to Plato, however, was not so much the study of Plato as the emancipation from the authority of Aristotle, and this meant nothing less than the emancipation from the yoke which church scholasticism had placed upon mind; as the spirit threw off the chains of Aristotelianism it ushered in the age of free thought and criticism. There was Platonism in the church, it is true, but only the idealism of Plato; the church took no account of the master's questionings, of that Socratic elenchus which has been and still is at the bottom of all progress in all the domains of human activity.

The Florentine Academy. True Platonism had been in Italy among the early leaders of Renaissance, as we know, but the man who breathed a new life, a new enthusiasm into it, and who thus was probably the father of all later Platonic academies, was Gemisthos Plethon, of Greece. Plethon ( 1355 - 1450) was a man who had the greatest reputation for his wisdom and his justice. It is said that people, even the wise and the great, came from all corners of the earth to see him. $\mathrm{He}$ was a great teacher and had gathered around him a kind of society, a sect of followers, as he himself considered it. Manuel Chrysoloras and the later famous Cardinal Bessarion were among his pupils. Bessarion was his pupil since 1415 and was near him till 1436 .

Plethon stood in great favor at the court and for a long time held an appointment as judge. When the great union council was held at Florence in 1438 to bring together the eastern and the western church, Plethon was sent by the emperor as a representative of the east. It is said, however, that he had no interest in the union of the two divisions of the church, but devoted his energies toward expounding his own ideas to the Italian people. Schultze says: "It was not the consultations at the council, but rather the free intercourse with the Romans that roused the activity of Plethon. In those dry sessions he spoke dry words which did not come from his heart; it was in living conversation, that came from the depth of his soul, that he kindled the Italian spirits into such a glow that they lit up, not only Italy, but later the whole of philosophizing Europe." Plethon found in Italy already an enthusiasm for the Greek muses, and especially for Plato in philosophy, and so he was listened to with the same enthusiasm with which he spoke.

Gregorios Monachos, one of his disciples, says: "The best of the Romans were so astonished at the irrefutable proofs of this man that, though they at first tried to refute him and made numerous efforts to do so, they finally gave up all their self-conceit and expressly admitted that they knew nothing." 
From him, however, they wished to learn, and in his friendliness he was quite ready to give them his assistance. Hieronymos, another contemporary, said: "How the Romans were astonished at his wisdom and his virtue and the power of his speech. He shone amongst them more brilliantly than the sun. Some praised him as the common teacher and benefactor of man, others called him Plato ${ }^{1}$ and Socrates." Amongst these admirers was the young Pomponius Laetus, later the leader of the Roman academy.

Villari says : "So admirable were his writings that it was difficult for the best philologists to distinguish them from those of the brightest period of Grecian literature." And Giacomo Leopardi, than whom, according to Villari, there can be no better judge, says: "with such abundance and weight of authority, with so much sobriety, power, and elevation of style, purity and refinement of language, that the reader is tempted to pronounce Gemistos, the equal, in all save antiquity, of the great Grecian writers of old. And this was the verdict of the learned of his own land in his own age." (Taken from Villari, Life and Times of Savonarola.)

It was due to the inspiration given by Plethon that Cosmos the Great founded the Florentine academy whose fruitfulness for the study of Plato and so also, not only for philosophy but for all humanistic science, has been of the greatest importance. When Plethon saw that he had kindled a passion for the new ideas in Cosimo, he went a step farther and communicated to him his cherished plan of establishing in Florence a revival of the ancient academy that had won so much glory for Greece. Cosimo was enchanted with the plan, took it up eagerly and set to work to carry it into effect. As soon as Gemistos had left Florence, however, Cosimo saw that the Platonic academy could not possibly flourish without some ruling spirit at its head. Hence he had Ficinus, the son of his physician, educated in Platonic studies, and with so much success that Ficinus translated the works of Plato and of the Neo-Platonists so masterfully that they have been reissued from time to time till the present day. To this great circle of Platonists who considered Ficinus their teacher, Reuchlin, the advance guard of humanism in Germany, belonged. And Reuchlin's teachings in turn were the foundation of Melanchthon's humanism, so that Plethon's influence is present in the German Reformation.

Upon the death of Plethon, Cardinal Bessarion wrote a letter

1 It was here in Italy that he added Plethon to his name, which was Georgeos Gemistos; Gemistos means full and Plethon means $f u l l$. Schultze supposes that he probably adopted Plethon, having the same meaning as Gemistos and sounding more like Plato. His enemies, at least, took this change of name as a sign of his arrogance. 
to the sons, saying: "I have heard that the father and leader has gone to heaven leaving behind all that is earthly, in order that he may dance the mystic dance with the Olympian gods. I am glad that I have had the companionship of a man than whom Greece has produced none wiser since the days of Plato and Aristotle. If one would assume the endless transmigration of souls as taught by Pythagoras and Plato, one could not hesitate to believe that the soul of Plato had come down and chosen the body of Gemistos for its abode. If you do not feel the greatest joy to be descended from this man, you do a great wrong. To bewail such a man is not proper. This man made Hellas famous and will be its ornament in time to come. His memory will not fade; his name and his fame will be handed down to posterity with everlasting praise."

In Italy Plethon's name was not forgotten. In the Florentine Academy Plethon was revered as the prophet of Plato and he was looked up to almost as a new saint.

As to the organization of this Florentine Academy Brandi says it had no statutes and no organization. The members were held together by their own love for learning and by the personal influence of the Medici. They met in the splendid country villas of the neighborhood, mostly in Careggi; they held plain meetings on the blooming meadow or on the mountain top; or they held a great social banquet on the model of the Platonic Symposium. Such a banquet was held regularly on Nov. 7, the birthday and the day of death of Plato.

The Roman Academy. The Roman Academy is one of those of which we know most, and yet we do not know its origin. We know definitely only that Pomponius Laetus was at the head of it for some time. This man, as we have seen, in his youth, had heard Plethon in Florence, and was undoubtedly inspired by his enthusiasm.

Laetus was born in 1428 in Dianium as the son of Prince John Sanseverini. He seems, however, not to have used that name but appeared as Peter of Calabria and later under the humanistic name of Giulio Pomponio Leto. A family quarrel caused him to leave home, and giving up all claim to his descent, he went out into the world to make a career for himself. He first went to Sicily, probably because he had friends there; later he came to Rome to be near Laurentius Valla, for during the reign of Pope Nicholas V (I447-I455), and under the influence of Cardinal Bessarion great liberty was enjoyed by the humanists in that city. Keller thinks that we may safely assume that the academy already existed at this time. For reasons unknown, Laetus crossed the Alps and went into the valley of the Danube, from whence he went to Bohemia and to Poland. Then he turned and went to Greece returning to Italy by way 
of the Agean Islands. He settled in Rome, purchased a home of his own in which he organized a museum, and we soon find him at the head of the Roman Academy.

The descriptions of this, as of other academies, vary according to the sources from which they come. The church, quite naturally condemns them severely, whereas more impartial historians take a quite different view. Pope Paul II said of the Roman Academy in substance: "They deny the existence of God. They declare that there is no other world than this, that the soul dies with the body, and that accordingly, man may give himself $u$ p to the indulgence of his passions without any regard to the law of God; all that is needed is to avoid coming into collision with the temporal power. They despise the commands of the church, eat meat on fast days and revile the Pope and the clergy. They say that the priests are the enemies of the laity, that they have invented fasting and forbidden men to have more than one wife. Moses, they teach, deceived the Jews, his law is a forgery; Christ was a deceiver, Mahomet a great intellect but also an impostor. They circulated predictions of the speedy death of the Pope when a new election would bring about a complete change in the state of affairs.

Most of what we know of this academy comes from the popes, who were hostile to it. The best representatives of these academies emphatically call themselves Christians, though orthodox theologians again and again call them heathens and atheists. Impartial modern historians do not take these charges very seriously; they realize that, though most flocks have their black sheep, the leaders of these academies were usually men of high ideals.

In I 468, however, Paul II accused members of the Roman Academy of heresy and ordered Laetus and about 20 "poets" and "philosophers" arrested. Many of the members were absent, some were arrested and tortured so severely that it is said many of them died. Laetus was in Venice at the time. Here he lived three years in retirement. But when the Pope asked for his extradition, Venice yielded and he was led to Rome and in chains he had to parade the streets. In about a year all were given their freedom, the academy was dissolved and all threatened with punishment as heretics if they would violate this decre. The trial, however, threatened to develop a great sensation, because the academy had powerful friends. Cardinal Bessarion, for instance, when the trial was in progress (1469) issued a pamphlet defending Platonism, and opened his house to students and lovers of Plato, not only of Italy but of other countries as well. Neighboring countries became mixed up in the affair. King Ferdinand of Naples was a protector of academies and they had powerful friends north of the Alps; in 
short, their connections were such that even Paul II had to draw in sail and give the prisoners their freedom.

After the Roman Academy had been dissolved we hear nothing of it. The members kept absolute silence, contemporaries say nothing except record the common gossip of the day, and we should suppose that this academy ceased to exist after the persecution. However, in $185^{2}$, DeRossi found the name of Pomponius Iaetus and others written on the walls of the catacombs. Many of the names are unknown and have thus far not been solved. Pastor, who represents the Catholic view, says, since these "modern heatheus ventured into the venerable vaults of the catacombs where the very stones preach the gospel, to scrawl flippant inscriptions on the walls," we cannot wonder that contemporaries called them heathens rather than Christians. Keller, who represents the opposite view, says: "It is not too far fetched to believe that in these subterranean temples, filled with hallowed memories, these faithful servants of truth in secret kept burning that torch of progress which the powers that were so often tried to befog or destroy.

When, in I47I, Sixtus IV came to the throne be followed the opposite course of Paul. He recognized the academy. Their meetings were open; bishops and priests belonged and they obtained many valuable privileges. It was supposed that with the establishment of privileged academies the free academies would cease. The former, however, had not only literary men as members, but their membership included kings, princes and nobles, scholars, poets, builders, sculptors, masons, and even men without qualifications. That such a society is not the means for men of high scientific ideals to accomplish their ains seems natural. So it came that beside the public academy there continued to exist the free and secret acadenly. Laetus remained at the head of both till his death when he was followed by the poet Angelo Coluzzi seemingly as head of both academies. It is difficult to follow the history of the academies, but certain it is that in the middle of the 16 th century Pope Paul III (died 1549) looked upon certain academies as hotbeds of the Reformation. And it is known that the Inquisition held that the pamphlet "Sommario della Sacra Scrittura" (The Sum of Holy Writ) which was widely circulated over Italy in $\mathbf{r} 53$ and was one of the most famous of all reformation pamphlets, had originated from the academies; and the pamphlet actually found some defenders in the academy of the Grillenzoni, in Modena, in 1537 .

The influence of the Roman Academy was very great, not only in Italy but also on the other side of the Alps as we shall see presently. Barthold says that at all seats of learning such. societies were formed, modelled after the Roman Academy; that 
nearly every palace was changed into an academy of science and a temple of the Muses, especially in Mantua and Milan; that all these academies at one time or another, besides classical antiquity, gave attention to the mother-tongue; that Florence, Venice and Bologna rivalled in the cultivation of "belles lettres." This last is especially significant in connection with the German "Sprachgesellaschaften," to be treated later. The number of Italian academies, both scientific and literary, is variously estimated at from a few hundred to 700 . In some of them experimental science was cultivated: such were the Academia Sacretorum Naturae, founded in Naples in I560 under the presidency of Baptista Porta; The Lincei in Rome by Federigo Cesi which issued valuable publications and of which Porta, Galileo and Colonna were members; and Academia del Cimento founded in Florence in 1657 under the advice of Viviani, one of the greatest geometers of Europe, and of which Toricelli, the inventor of the barometer, was a member.

The Neapolitan Academy. Another famous academy is the one at Naples under Alfonso I, next to the three Medici the most noteworthy person of the Renaissance. He collected around him a number of scholars and devoted large sums of money to science; it is said that he spent 20,000 ducats annually for this purpose. The most famous of this group of scholars was Antonio Beccadelli, or sometimes called Palermo Antonius Panormita (born I 394 or 95), who first made humanism at home in Naples. He had met the most famous humanists at the court of Florence, such as Poggio, Niccoli, Cosmos de Medici, Leon Battista Alberti, and he took great pains always to keep up good relations with the Florentine circle. He was at the head of the Neapolitan Academy and Alfonso furnished him lavishly. He presented him with the magnificent palace Zisa with its orange gardens and fields; a villa in Portici; a palace in Naples; and when he went to a princely wedding at Venice he went with twenty servants and received 850 ducats for his expenses.

Gothein says, his academy, in which he preferred to inspire rather than work himself, was held together not by its relations to the royal house, not by a kind of public recognition, not even by the intellectual problems which it had set itself, but rather by a personal friendship the intensity of which was increased by the feeling that they were a society of a higher culture in an essentially different world. Though Panormita had made it a law of the acadeny that a grammatical essay had to be read at every session, the grammarians, who were the teachers of the young, were the enemies of the academy. One can readily understand this when one remembers that it was not "Gelehrsamkeit" that was carried on by this group of scholars, 
but above all "die Wiederbelebung des antiken Lebensinhalts" as Gothein puts it. Personal friendship was a more important bond of union than common studies. As with the Florentine Academy and the Roman Academy under Pope I,eo X, the fusion of friendly sociability with literary debate was a necessary of life.

Valla was for a time a member of this circle. Luther was a student of Valla's works. Gothein says, it was Valla who gave Luther the conviction that the claims of the Papal power rested on a fictitious basis, that the real basis of the church cannot hold its own against criticism.

The Crusca. One of the most famous academies of Italy, and one which has had a greater direct influence on the development of similar societies north of the Alps, and one of whose history we know more than of any other, is the Accademia della Crusca. It was founded at Florence, in 1582, by Cosmos de Medici by giving au official form to a private academy which already existed. Its original membership was five, but the same year a sixth member joined named Lionardo Salviati; it is he who drew up the plan for an Italian dictionary, a work, Reumont says, which alone would have made him famous. Though its members were mostly Tuscans, yet it had foreign members, and during the I $7^{\text {th }}$ century a great number of the most brilliant men of Italy belonged to the society, and Reumont says, its activity corresponded to the brilliancy of the names which adorned it. As early as I 586 Virginio Orsini, Duke of Bracciano, the most brilliant nobleman of Italy, was a member. Reumont says in the 264 years of its existence it had 976 members, native and foreign. Each member had an academy name, a "Sinnspruch," and a "Sinnbild." Many of the nobility that belonged supplied the academy with funds. The house of the Medici stood by the academy for 200 years and sixteen of the princes or this house were members. Amongst its membership were one Pope, Clemens XII, and many cardinals. From the time of its beginning till 1857 , seventy foreigners belonged, as follows: Thirty-eight French, sixteen German, six English, four Scandinavian, two Polish, two Dutch, one Greek and one Spanish. Many foreigners were admitted complimentary, but in most cases the appointment was due to service rendered to science and to literature. Some foreigners had the twofold distinction of representing their government at the Tuscan court and of being a member of the Crusca.

The aim of the academy was to purify the mother-tongue, or, as its name indicates, to separate the flour from the bran. In thus establishing a literary language and in limiting the dialects to their proper spheres it did a great thing, such as, 
Reumont says, is rarely attempted and still more rarely prosecuted with equal skill and equal success. To attain their end they thought it best to work out a dictionary, and so we find as early as March 6, I591, the plan of a dictionary discussed. Not before the spring of 1597 , however, were definite rules adopted as to the plan as a whole, definitions, etymology, orthography, arrangement of the subject matter, the citing of modern authorities, etc. Four members were given the direction of the whole work, but it was soon found that the task was entirely too much for them and fifteen more were added, making the number nineteen.

That these nineteen men lost no time in getting to work is shown by the fact that in May, 1606, the first revision of the dictionary was completed; that in October, I6ro, the secretary of the academy, Bastiano de Rossi, was instructed to arrange for the printing of the complete work in Venice; and that in I6I2 the Vocabolario degli Accademici della Crusca appeared in a folio volume. Just thirty years had elapsed since the founding of the academy. Eleven years later a second edition was issued with some additions and corrections, and forty years later, I68I, the third edition appeared in three folio volumes. In this edition the range of authors cited and compared was widened and etymology received more extensive attention.

The Crusca also issued a corrected edition of the Divine Comedy in I595. They felt the need of this because it contained the better part of the language and had been ruined by commentators. They took as a basis the Aldine text of I502, but compared it with various other manuscripts and added other versions in the margin. This edition became the model for the majority of the later editions.

The greatest work which the academy carried out in the first half of the I 8 th century, and, Reumont says, the greatest work of its kind which any learned society has ever carried out, is the fourth edition of the dictionary, which appeared I729-I738 in six folio volumes. Reumont says that up to the present time this fourth edition has been the basis of all lexical work in Italy. It was reprinted with more or less changes and additions in Venice in 1741 and 1763 , in Naples in 1746 , in Verona in 1806 , and in Florence in 1833 . It has met with much criticism, but the academy's service to the language, Reumont says, even envy and prejudice cannot deny.

The foreign members, it is true, could not help much toward a dictionary, but they, each in his way, spread the knowledge of, as well as appreciation for, the Italian literature by means of translations or annotated editions of the great Italian masterpieces. Not only that: these foreigners, above all, carried across the Alps that spirit of brotherhood, and that passion for 
co-operative investigation of truth outside of the narrow bounds of scholasticism, which was destined to yield such fruitful results in future years. Among its foreign members were not only poets and literary men, but princes and philosophers, historians, archæologists and natural scientists.

Furthermore, this academy became the model directly of at least two other famous societies, of the Old French Academy, in I635, and of the "Fruchtbringende Gesellschaft," founded by Ludwig von Anhalt in 1617, both of which societies gave their attention largely toward the development and purification of the mother tongue.

\section{ACADEMIES NORTH OF THE ALPS.}

Academies of Conrad Celtis. The academies of Italy, however, made themselves felt in northern Europe long before the "Fruchtbringende Gesellschaft" was formed. Numerous European scholars in travelling through Italy became acquainted with, and often became members of, the academies. Among these wandering scholars, and one of the most famous of them, was Konrad Meissel, or, as he later called himself, Conrad Celtis Protucuis, who was a poet of some note, being crowned by Emperor Frederic III in 1487 .

Celtis (1459-I508) had a great desire for knowledge. $\mathrm{He}$ fled from home and went to Cologne to study, but soon tired of scholasticism there, he travelled far and wide, and in I 484 came to Heidelberg. This was at the time a great seat of humanism and here he matriculated under the academic name of Conrad Celtis Protucuis. He soon so won the respect and love of Dalberg, Agricola, and Plennigen that they admitted him to their "Zwanglose Gesellschaft," a society modelled after the Roman Academy. After he had visited Erfurt, Rostock, and Leipzig, he went to Italy in 1486 and heard at Padua. Ferrara, Bologna, Florence, and Rome the most celebrated humanists. Having sat at the feet of Pomponius Laetus, and having been urged by him to found similar societies in Germany, he returned by way of Venice and founded in Germany academies for classical studies, modelled after the Italian. It is said that he founded eight or nine such academies in different parts of Germany of which the one at Vienna and the one on the Rhine were the most noted. Some of his academies, it is true, may hardly have outlived the presence of the poet, yet with some the influence of classical antiquity remained longer.

The great Sodalitas Rhenana or Celtica was founded between I 487 and I49I; it was a humanistic society which united the noblest minds in the valley of the Rhine. Little is known of the constitution of this society, but it is known that it had one law, namely, that all manuscripts published by the society 
were to be examined by the members. This society had a letter of protection from the emperor copyrighting its publications, and it regarded itself as a kind of overseer over all the other societies of the life of which we know little.

The society at Vienna was quite comprehensive and successful. It was the centre of humanism in the valley of the Danube, for Germans, Bohemians, and Moravians. Here classical forms of poetry were successfully imitated. The members presented each other with loving cups accompanied by odes full of inexhaustible praise for genius. Every work of the muses here, however, was in antique form; the very universality of the society prevented it from doing anything for the vernacular. One of the plays of Celtis, entitled Ludus Dianae, was played before the emperor at Linz by twenty members, four of whom were crowned with laurel, and all members present were served from golden vessels.

The society of Wittenberg was the one where the celebrated Bohemian Bohnslav Lobkowitz von Hassenstein "had his love for the humanities aroused which he carried with such beautiful success to his countrymen."

When Conrad Celtis, "burned out by the fire of his soul and his senses," died Feb. 3, I508, at Vienna, at the age of 49, the academies continued to live for several years, but they soon disappeared in the storms of the reformation. These old academies, however, had not lived in vain in so far as they "strove against hide bound scholasticism in church and school and made it possible that the Latin Muse could, in the I6th century, be represented by the gifted Hessian, Coban."

Barthold says, that though antiquity was the centre around which these societies moved, and though they held close to the purity and elegance of classical models, yet they drew into their circle not only Florentine Platonism but also mathematics, astronomy (astrology), and music. He says this academy investigated the remains of Roman antiquity in Germany and studied inscriptions and monuments and thus opened the way for German history and its sources. Celtis rendered great service to history by finding the so-called Tabula Peutingeriana and by discovering in an unnamed Benedictine cloister the handwriting of Hrosvita, the oldest German poetess, which he published in I5OI. Keller says that though these societies devoted themselves to poetry, to the publication of ancient classics, and to the cultivation of the vernacular, even calling themselves poets, yet it needs be noted that some of the members were not poets and that there were very few poets who did not at the same time devote themselves to astrology, cosmography, geography, alchemy, etc., and that among these "poets" we find prominent tradesmen such as printers, paint- 
ers, sculptors and others. Moreover, just as Paul II felt that there was a connection between the Roman Academy and the Bohemian heretics, so the German clergy accused these "poets" of heresy.

These academies did really nothing for the mother tongue though they translated many classics and meant to give the vernacular the same flexibility and richness they so much admired in the ancient languages. To bring about a regeneration of the German language by means of classical models failed. Barthold says German poetry became silent with the death of the Frankish warrior of freedom, Ulrich von Hutten, who was crowned at Augsburg in I5 7 . The succession of Charles V to the German throne was a national calamity. Luther, it is true, secured the dominance of German in the Protestant church, in popular expression and in church poetry, but scientific German did not profit thereby and the poetic genius of the people was threatened with extinction during the fierce battles for freedom of conscience. At the time when the Italian Muse, cultivated by numberless societies of linguists and poets, reached its apex with Tasso, in Germany the period of barbarism in language set in. And during this very period of darkness in German history and German language, the "Fruchtbringende Gesellschaft"' was born; to this society we shall give our attention in a later chapter.

The Bohemian Brothers. Humanism, however, was carried on not only in secular academies but also by religious organizations, such as the Bohemian Brothers and Waldensians. These were of course sects, "heretics," which stood outside of the Catholic church and were severely persecuted by it. They were probably the representatives of that independent spirit which refused to bend the neck to the yoke which the Catholic church ever since the early Christian centuries tried to force upon all religions within the bounds of the Roman Empire.

$\mathrm{J}$. von Döllinger holds that the sects of the middle ages are connected by a series of members with the sects of the first and second Christian centuries, and believes that at the beginning of this series of development are those sects which are commonly called gnostic. He says gnosticism had spread all over the Roman Empire, and even beyond its boundaries, in the middle of the second century.

Keller says that the inner relations of all the sects, from the early centuries to the middle ages, is so striking that one can only explain them by assuming a common origin of them all. He thinks that the most important doctrines of these sects began their development with the early church fathers, and from the east gradually spread northwestward over Asia Minor, Bulgaria, Dalmatia, Upper Italy, Southern France, thence to Ger- 
many, Bohemia, Poland and England. During all these centuries their convictions had to maintain themselves against persecution, and that often of the severest kind. It was common during those times for men to have two religions, the one public-per force, the other the one they believed and which they practiced in private. This is an important fact to bear in mind when one studies the organization of these "heretical" churches.

These old evangelical churches had three degrees:-Socii, Fratres and Perfecti. It was the Perfecti who elected the brethren and who supervised the whole temple. The Fratres formed a kind of an academy. Keller thinks that undoubtedly many churches consisted of only Socii who did not know that they formed a part of a ring of "heretics." Often these churches, especially when religious storms were raging, existed only as literary societies, or as inner circles of legalized organizations such as trade guilds, building corporations, laboratories of princes, and printing offices. In this way they could follow their own ideals unmolested. Thus we find not only a close relation between the Bohemian Brothers and the academies, but in many cases in Bohemia they were one and the same thing. What this means to education we shall see later when we note the relation of Comenius to the academies.

Among the Bohemian Brothers, in the I5th to the I 7 th centuries, there were many so-called literary societies which had to withdraw into secrecy during periods of religious storms. The membership was composed of men of all classes and all professions, often they even had members of all confessions. Some of these societies had their own houses in which they had their own libraries, their own entertainment rooms and sometimes their own school. Like the Italian academies, they cultivated music and poetry, mathematics and natural science, as well as the vernacular. They aimed also to enhance the glory of God, virtue and good morals, and to foster and disseminate peace and good will among mankind.

Though we know nothing of their rules and regulations, we do know that in the history of Bohemian and Moravian humanism these societies played a great rôle. Barthold says in substance: "No slavic race had had such a golden period of spiritual culture, of wealth and of splendors as the Bohemians had from the time the Hussite storms had subsided till the time of the second Rudolph. Bohemians were among the rivals that competed for the prizes in Celtis' academy; some of them ranked among the best, especially was this true of Nicholaus Troylo, professor at Prague, who in 1627 became a member of the 'Fruchtbringende Gesellschaft.' Printing flourished among them, and we find the most select libraries in Bo- 
hemian cities in the palaces of the cultured rich. In the r6th century, while Germany was still Latin, the Bohemians began to write their own history in their mother tongue, and though the Catholic clergy held to Latin, the nobles of both confessions promulgated national works in the Czech tongue."

After the defeat of the Bohemians all this changed; the Protestants were driven out of the country, and even the Catholics who had belonged to these societies were placed under close surveillance. The societies were by force changed to church fraternities, and in place of the "senior" a priest was placed at the head. In their houses church services were held and masses were read, and the members had to participate in the choirs at processions and church festivals. During the very time in which these literary societies were destroyed in Bohemia and Moravia we meet for the first time the activity of the "poets' and their "Sprachgesellschaften" in the Empire and especially so in Silesia. Martin Opitz, the personal friend of Comenius, was their spritual leader and he and his friends made the dialect of their province the leading idiom of the age.

It is significant here to note the relations of the Bohemian Brothers and the other old evangelical churches to the orient and to the Greek church on the one hand, and to the guilds and the academies of natural philosophers and alchemists (to be treated in a later chapter) on the other. This complex interrelationship may be the means by which we may finally bridge the chasm between the sixth and the $15^{\text {th }}$ century.

Academies and Labor Guilds. From early Christian-may be from prechristian-times the labor organizations have been among the carriers and disseminators of science and liberal ideas. It is probable that as early as the time of the Pharaohs the technical knowledge of masonry and architecture was cultivated by the guilds and that the same is true of the weavers, just as the inner circles of guilds during the middle ages carried forward the "secrets" of their trade, one of which was geometry. It was in these inner circles-often called academy-that the master workmen were educated. Moreover, wherever the guilds flourished, the academies flourished also, and, Keller says, the words "Zunft" and "Hansa" (guild) were often used to also designate the academies, and that many of the members of the academies of natural philosophers were the sons of guild-brothers, all of which points to a close relationship between the two organizations. He furthermore says: "It is a noteworthy phenomena that all the great artists who carried forward the spiritual heritage of Dante and Petrarch grew up in the soil of the trades and that they found and recognized not only their social but also their spiritual home in the academies which in their turn rested upon the guilds. The 
great ideas of antiquity, and especially the philosophy of Plato and the religious convictions of early Christianity formed the spiritual bond which united these trades and their academies into a long chain; and it was the ideas, convictions, and principles of these academies which inspired the poets and artists to their creations and opened new modes of thought and action to humanity."

Again, when in the last decades of the I 3 th and the first decades of the I $4^{\text {th }}$ century the church and the state were in bitter conflict and the Waldensians and other heretics were gaining adberents all over Europe, even among the nobility and the clergy, many members of the guilds, especially of the masons, adopted reform ideas and thus, beside carriers of technical science, these guilds became the propagators of brotherlylove and of toleration. It was also these guilds which offered to the heretical schools at the beginning of the reformation their best support and their best means to hide their existence. Döllinger says, that wherever the guilds were well represented heretical religious views were also well disseminated. The relation of the Bohemian Brothers to the academies of natural philosophers will be pointed out later.

Die Fruchtbringende Gesellschaft. It is a matter of history that as "heresy" was suppressed in one place or country it broke out in another. The alchemists, natural philosophers, and heretics had a secret means of communication all over Europe, and so we find that just as the Bohemian and Moravian societies are forced out of existence, across the border in Germany other societies with other names spring into life. In Germany, however, we meet with two kinds of societies, the so-called "Sprachgesellschaften" of the history of which something is known, and the societies of naturul philosophers of which we know very little. These two classes of societies were undoubtedly closely interrelated, since their organizations were very much alike and members of one were often also members of the other-in some instances there was probably very little difference in purpose and in aim.

By far the most prominent of the "Sprachgesellschaften" is the "Fruchtbringende," sometimes called "Der Palmbaum," founded by Ludwig von Anhalt in 1617. It has already been pointed out that it was an imitation of the Crusca in Florence which was chiefly a language society and of which Ludwig was a member. The aim of the society was set forth by Ludwig as follows : Der Zweck ist allein auf die Deutsche Sprache und auf löbliche Tugenden . . . . . gerichtet. In the regulations of the society, however, conduct is placed first and German second. Though one can see that for patriotic reasons these men should strive for a better development of the mother tongue, yet it is 
a fact that none of the eight founders were literary men and many of its later members were not; neither could the foreign members, many of whom were Bohemians and Austrians, be of much service toward the development of the German language. The bond that held them together was probably a sameness of philosophical and religious conviction. Religion was not a bar to membership; though the majority of the members were Protestants, yet we find some Catholics among them.

At first the society gave its chief literary attention to translations. Translations had been made heretofore, it is true, but then chief emphasis was laid on context, now more attention was given to form. Later, two grammars of the German language were produced by members of the society, one by Schottel and one by Gueinzius. The latter's book was published in I64I and was officially recognized by the society as the German grammar, though in some places Schottel's work was received with favor.

When one looks at a page of German of this period one can readily understand why patriotic Germans should feel the need of cultivating the vernacular. It was a mixture of German dialect, Latin, French and what not. Even the peasant in his conversation would feel himself on a higher plane of culture if he could patch in here and there a Latin or French word. Martin Opitz ( 1639 ) complains that everybody who wishes to appear cultured uses a few foreign words on every possible occasion. Iratin had indeed rooted so firmly that Opitz suggests that in reforming the German the foreign endings of proper names be retained in order not to offend too severely.

The "Palmbaum"' was a secret society; it kept its activity so secret that thirty years elapsed before traces of its constitution, symbolism, and membership became faintly known to the public. When, in 1673 , the society was on the verge of dissolution its membership became known, and the world was astonished to find among the 789 members not only citizens and scholars but many powerful German princes. Among the foreigners we find King Charles Gustave of Sweden, the Great Elector of Brandenburg, and the great chancellor Oxenstierna; among scholars we find Harsdörfer, Bernegger, Opitz, Dornau and many others all of whom were pupils, friends, or admirers of Hugo Grotius, Galileo and Campanella.

As to the influence of the "Fruchtbringende Gesellschaft" opinions differ. Some think it was of little importance. Yet this society was the first to bring together a number of prominent men opposed to the "Sprachmengerei"' in Germany, and it cultivated a feeling of patriotism during the thirty years' war when patriotism was at very low ebb. It produced a com- 
prehensive German grammar, did much for orthography and versification, and took steps toward the compilation of a German dictionary, ${ }^{1}$ but its great service was the purification of the German language. Within the society the principle of equal rights was recognized. When, 1647 , it was suggested that only men of noble birth should be admitted to the inner ring, Ludwig objected and replied that scholars are noblemen. Furthermore, woman's equality with man was defended here. The work of the society was so well recognized that it was quite an advertisement for a book to have on its title page "Member of the Fruitful Society."

There were other societies for the purification of the German language, mostly imitations of the "Palmbaum," in which the tendency to go to extremes was often very strong. "The "Palmbaum," was characterized by its moderation; its members constantly advised to keep foreign words that had become Germanized. Schultze says, "We to-day, in the matter of purifying the language, stand on the shoulder of the "Fruchtbringenden," we carry forward what they began and would indeed have much more to do had those men not so well prepared the way." Barthold says, "Through the efforts of this forgotten society our classical poets found a purified language which naturally adapted itself to poetic thoughts . . . . . such faithful sentinels of the language as Morhof, Leibniz, and Gottsched took courage when they thought of these never to be forgotten early champions." And we to-day agree with him when he says, if a language accepts complacently foreign elements, its deepest fountains dry up and not even the gods can bring back its original strength.

At the beginning of the 18 th century attempts were made to found language societies on the model of those of the preceding century, and later we have as scientific continuations of the earlier "Sprachgesellschaften" the present German societies of Leipzig, Göttingen, Helmslädt, Jena, and Greifswald. About the time this society was organized Ratke, the man who first introduced German into the schools and into science, at the call of Ludwig, organized a school at Köthen, and Krohmeyer drew up the famous school ordinance for Sachse-Weimer which demanded that during the first three school years the main stress should be laid on the German-all this almost seventy years before Thomasius gave his first German lecture in the university.

The following are language societies modelled after the

1 Ludwig bargained with Schottel for a German dictionary, but he did not publish it though he had collected much material. In I67r the London Royal Society sent word to the "Fruchtbringende" that they expected a dictionary from them. 
"Fruchtbringende :" (I) “Die Aufrichtige Gesellschaft von der Tannen," founded in I633. (2) "Die Deutsch-Gesinnte Genossenschaft und die Neun-Stündige Hänsesschaft," founded by Zesen I 643 or I644 in Hamburg. (3) "Die Peguitz-Hirten Gesellschaft," founded at Nürnberg by Harsdörfer in I642 or I644. (4) " Der Elbische Schwanen Orden," founded by Rist in 1656 .

We meet here and there with the names of several other language societies, but whether they were only planned or whether they really existed, is not known. Such were : "Der Belorbeerte Tauben Orden." "Die Teutschliebende Gesellschaft zu Regensburg." "Der Leopolden-Orden." "Die Görlitzische Poetische Gesellschaft."

Of all the language societies the "Fruchtbringende" was the strongest in membership, both as to number and to quality. It had more than three times as many members as any one of the others. It was the most productive, and none of the others practiced such wholesome moderation in their work of purification.

Academies of Natural Philosophers. Keller thinks that the real nature and influence of the "Sprachgesellschaften" has not yet been properly understood. He says, it is true, a number of modern investigators admit that the turning point in German literary history, connected with the name of Martin Opitz, could not have occurred so rapidly and so thoroughly without the energetic help of the "Fruchtbringende Gesellschaft," but that these same investigators fail to see that this society had a larger aim than a renewal of the national language and literature, that it rather (vielmehr) offered refuge and support to all those men who worked at the reform of scientific as well as spiritual life. He says the development of the mother tongue, thoroughly as it was in harmony with the general principles of the academy, for the initiated it was only the cloak which shielded their highest aims from the eyes of dangerous opponents. All recent investigators, he says, have been misled by taking the shell for the kernel. During the stormy years of its existence it was desirable to avoid all suspicion of politics and church politics and to adopt as a bond of union a goal that was practical and attainable. He would place them practically in a category with the societies of natural philosophers.

It is true, he says, that the members that were most active since 1622 were dominated by linguistic and literary interests, yet in the admission of new members greater stress was laid on likeness of sentiment and endeavor than on the German language. It is significant here that, as has been said, none of the eight founders were active, neither in the science of language nor in literature. Keller thinks it is also significant to 
note that these academies, which really had had already a rather long history in Germany, began to develop more extensively during the very time when the "Gesinnungsgenossen" of Ludwig von Anhalt had gained a series of great and important political and religious successes; that in England their development was connected with the rise of Cromwell only to take on a different development after the restoration; and that in Germany after the victories of the counter reformation, Ludwig's academy directed its activity into other and more harmless channels.

Again, in 1647 , Karl Gustaf von Hilles issued a pamphlet in defense and praise of the "Palmbaum" in which he said that within the society there were "secret things"' which were known only to those who had the privilege to enter the castle at Köthen. ${ }^{1}$ Keller thinks this is inexplicable if language and grammar were the sole aim of the society.

It is interesting to note here that only two preachers belonged to the society. J. V. Andreae, and Joh. Rist, both of whom got into trouble with the church because they were considered "Schwärmer" and fanatics. The latter belonged to the natural philosophers; in his house were a universal cabinet, distilling, and also mathematical apparatus.

Harnack does not agree with Keller that the mother tongue was only the cloak to hide the real aims of the academies from their enemies. He says, the vernacular and the new science went hand in hand; the spirit of the age expressed itself in natural science, mathematics, educational doctrine, and the vernacular. He would not deny that these societies stood for more than a cultivation of the mother tongue, but believes that the latter is an essential part of their activity. This view of Harnack seems to be sound. Their intense interest in humanity caused these men to develop vigorously the mother tongue, for it was only through the vernacular that they could reach the minds and hearts of the multitude.

Besides these so-called "Sprachgesellschaften" there were numerous other societies of natural philosophers of the existence of which we have only the merest traces. Their secrecy does not surprise us when we know that societies with such an innocent name as "Language Society" found it necessary, for fear of persecution, to keep their activity from the outside world. It was the alchymists and natural philosophers which were especially suspected by the church; they were suspected of belonging to the "Rosenkreuzer," an imaginary society supposedly of the greatest danger to the church, but which, in

1 The society first met at Weimar, but later at Köthen. It also had local organizations at Brieg, Weimar and other places. 
fact, never existed. This suspicion of the church caused the secrecy of these societies to be so close that we know little else about them than that their inner workings were like that of the "Sprachgesellschaften" and other similar societies, that alchemy was a kind of side issue, that philosophical interests were always in the foreground, that they had three degrees and that only those who were considered "safe" were admitted to the highest degree or "inuer circle."

These natural philosophers of the i 7 th century had had their predecessors. Through a long line of persecuted seekers after truth they had learned, had not their personal experience taught them, that no man is a prophet in his own country, and that to carry forward a great idea in the face of powerful and bigoted opposition it takes a firmly organized society. Alchemy itself was not new. Practical chemistry was known to the Egyptians of old. Through the Arabians it passed from the east to Spain, and from there it spread all over Europe. Emperors and popes issued edicts and bulls against it but without avail. In the $13^{\text {th }}$ century the great authorities in natural science, such as Albertus Magnus, Thomas Aquinas, Roger Bacon were in sympathy with it, and during the $15^{\text {th }}$ and 16 th centuries numerous rulers and princes on the continent and in England employed wandering alchemists. We can readily see the reason for this when we remember that some of the best chemists of the times, such as Basilius Valentinus, Paracelsus, Johann Baptist van Helmont, were found among the so-called alchemists, many of whom were earnest seekers after truth, and had no sympathy with cranks and charlatans, and objected to the names "alchemist" and "Rosenkreuzer" given them by their opponents.

From the correspondence of the members as well as from the attacks of their enemies we learn that quite a number of societies of alchemists and natural philosophers existed d during the $I 7^{\text {th }}$ century. Such societies were found at Vienna, Helmstädt, Lüneburg, Hamburg, Bremen, Erfurt, Danzig, Rostock, Nürnberg, Mantua, Venice, London, Amsterdam, and The Hague. In The Hague they even had a palace in which they held their meetings. It is known that in 1676 Johann Wulfert, a friend of Leibniz and later a member of the Berlin Academy, travelled through Germany to visit these societies.

The society at Rostock was founded by Joachim Jungius ( $587-1657$ ). Jungius was a man of great talent; he was naturalist, mathematician, and physician, and has been called the Bacon of Germany. He was a close friend of Leibniz and of Comenius and was a co-worker with Ratichus at his "Lehrkunst" in I6r2, and even at that time he planned the 
founding of an "Collegium." In I6I8 he studied at Padua, a centre for science, medicine and Platonic philosophy. In I6I9 he returned to Germany, spent several years at Rostock, where several friends of Valentine Andreae lived at the time, and there, in 1622 , founded an academy quite independent of the university, on the model of the Italian academies and called it Socielas Ereunetica or Zetetica, or Collegium Philosophicum." The aim of this society was, the investigation of truth by reason and experience; to strive to free the arts and the sciences from sophistry, to bring them back to demonstrable certainty, disseminate them by instruction, and increase them by happy discoveries. It was a secret society, but all transactions which were not especially designated to be kept secret, could be made public. Jungius, as did the members of other societies, kept close friendly relations with the artists and tradesmen and had them inform him on scientific questions which, from the nature of their trade, they understood better. In 1625, in the turmoil of the thirty years' war, this society ceased to exist.

From his own day to ours, Jungius has been ranked amongst the foremost thinkers. Leibniz in his later years planned to issue a collection of the writings of Galileo, Campanella, Pascal, and Jungius, and said he considered Jungius second to none of the others. Goethe and Alexander von Humboldt held similar views, and Harnack says he is in more than one sense a Leibniz before Leibniz.

Another society of special interest to us is the one at Nüruberg founded in 1664 . In 1667 Leibniz, at the age of $2 \mathrm{r}$, became a member and soon was made its secretary. This society had prominent men as members and carried on an extensive correspondence with similar societies in upper Italy, Germany, England, and Hollaud. The impressions which Leibniz received here, according to his own confession, remained with him through life.

One cannot leave this period without giving at least a brief account of Johann Valentine Andreae and his relations with, and influence upon, Comenius. Andreae's influence upon the men of his time can hardly be overestimated. He carried on correspondence with a very great number of men. With one of these men, who even did not stand very close to him, Brigel says, he exchanged in all 500 letters. "In order that life do not flit away without spice, I use the salt of friendship," he often said. He entered the University of Tübingen to study theology but early interested himself in natural science and mathe-

\footnotetext{
${ }^{1}$ He felt the need of a society for he said: "Wenn ich hätte allein sein sollen, so hätte ich keine Feder gegen die Schulmeinungen geführt." (Guhrauer.)
} 
matics. Later he went to Switzerland, France, and Italy and here began his estrangement from the prevailing orthodoxy. He associated much with tradesmen and mechanics and was perhaps well acquainted with the religious conceptions that prevailed at the time among the labor guilds. In I6I4 he returned to Wïrtemberg, wrote books which were widely circulated in Europe and were known to all the natural philosophers. He was a strenuous apostle of toleration and did a great deal to bring about religious peace. Though his opponents called him "astrologer," "Schwärmer," "sectarian," "fanatic," Spencer once exclaimed: "Could I, for the good of the church, awaken some one from the dead it would be J. V. Andreae." At theend of the 18 th century Herder studied his writings, and later Schleirmacher did so, and it was a pupil of the latter, P. W. Hossbach, who published in I8 I 9 the first monograph on the life of Andreae.

In Andreae's 'Christenstadt"' he advocates that men of different convictions should be allowed to live together, and to work for the same goal unmolested, and at the head there should be an academy or "Collegium" of scholars who were to devote their time to science. This idea was expressed before Bacon's "Novo Atlantis" was published.

Andreae was a deeply religious man but uncompromisingly opposed to the dogmatism and scholasticism of the church. He wished to overthrow the religious and the literary idols and place true Christianity in their place. And when, like Jungius, he found that individual efforts were not sufficient to carry out his ideas, he founded a Societas Christiana, of the activity of which we know little or nothing. He says in his biography that his burning love for the cause of Christianity had met on all sides with hate whenever he tried to advance it in a public manner, therefore he had seen the necessity of reaching his goal in a roundabout way.

Ever since 1617 Comenius studied the writings of Andreae with enthusiasm; it was the first step toward making him the friend and companion of the leaders of the academies. The more extended his correspondence became with the natural philosophers, and the more he became engrossed in mathematics and natural philosophy-which was about 1627 -the more active he became in the reform movements of the $17^{\text {th }}$ century. In I628 Comenius asked Andreae to admit him among his pupils and sons; Andreae accepted him and soon after sent him the laws of the "Societas Christiana"-but they have not yet been found. In 1629 Comenius asked for the origin and history of the society. Andreae grants his wish and replies in a long letter in which he says his aim had been to break the religious and literary idols and put Christ in their place; he expressed 
his great disappointment at his own failure and exhorts Comenius to carry forward the good cause which he says permits as co-workers all the peoples of the earth, but especially those Christians whose bond of union is exile. The history has not been found. Comenius himself calls him the learned and excellent Andreae and says, he, above all, deserves to be named among the men who worked at the improvement of the teaching method. He says Andreae gave the torch into his hand and cheered him on to risk something for the cause. How well he carried the torch the world knows.

H. F. von Criegern says that Comenius got his fundamental didactic and pansophic ideas from Andreae whom he often quotes literally, especially in his Labyrinth of the World. And Brügel says that Andreae laid the foundation upon which Comenius erected the admirable structure of his didactic. Comenius had also close relations with Hartlieb, Jungius, Harsdörfer, Dilberr, Zesen, Leibniz, Pömer, Wolzogen, Hübner and others. These men were the leading spirits of the age and the leaders of the academies of natural philosophers.

We have further evidence that Comenius stood close to the academies of natural philosophers. It is well known that members of the academies often used their symbol on their writings in order to stamp them as their own. Keller says Comenius used several such symbols which had been property of the academies since ancient times, one of them being the symbol which appears on the cover page of the "Monatshefte der Comenius Gesellschaft." Keller thinks he certainly would not have used these symbols without the consent of the academies. Moreover, the pansophical writings of Comenius were nowhere accepted with such approval as with the natural philosophers-not even with his own brethren. Comenius also knew something of the history of academies. He praised the Accademia della Crusca and the Fruchtbringende Gesellschaft and expressed the wish that among all peoples such academies might be founded. He realized that the academies working each for itself could easily be made the plaything of the powers that be, and that their influence would be largely local, and therefore he suggests in his "Via Lucis" that an attempt be made to form under a new name a higher organization of all the academies of all countries. He thought the time had come to unite "all sums with the sum of sums" and to found a Collegium Catholicum among the scholars of the earth. This Collegium, from the book of nature, from Holy Writ, and from the innate concepts of the members was to build up and improve pansophia; it was to cultivate a universal as well as the folk-languages; was to build and supervise schools in all countries, and was to have its beginning and centre in London under Crom- 
well. This idea of Comenius was kept alive in London by Hartlieb and may have contributed to the founding of the "London Society."

When one compares the activities and constitutions, the worldconceptions and the religious principles of the academies of natural philosophers of the 17 th century with those of the Bohemian Brothers and the Waldensians, one is immediately struck with the similarity between them. The following points of similarity may be noted:

I. The socii, fratres, and perfecti of the Bohemian Brothers correspond closely to the three degrees of the academies; and both had a picture language, secret recognition signs, as well as brother-names, all known only to the initiated.

2. The academies laid great emphasis on the mother tongue; and Gindley says no religious body has ever worked so emphatically and so systematically for the veruacular and for the establishment of a folk-literature as these Brothers.

3. While in the ruling church there was a great chasm between the rulers and the ruled, among the academies as well as with the Brothers, there was more democracy and all were encouraged to partake of the general culture and of all knowledge that was worth knowing.

4. Both believed in and worked for freedom of conscience; they refrained from forcing a religion upon others as much as they refused to have one forced upon themselves.

5. Though free from all confessional narrowness, and accused of heresy by the dominant church, both the Brothers and the Philosophers were mostly men filled with the deepest piety.

6. They preferred to emphasize the goodness of every soul and so brought sympathy and kindness into education, whereas the austere Luthern idea of the natural depravity of every soul led to unnecessary cruelty.

7. Both had a great love for nature; it is true, the Brothers did not accomplish much in this direction, but their very attitude was of great importance as compared with the attitude which considered all external nature as the work of the devil.

8. Both persistently advocated peace and good will to all mankind and especially were they anxious to see religious peace upon the earth.

9. The idea of the reformation of the whole world, advanced by the natural philosophers of the I 7 th century, is shown by Gindley to have been held by the Brothers as early as the 15 th.

Io. In the inner circles of both not only religion but also science was cultivated.

The men that belonged to these societies of natural philosophers were practical men. They held that science must mean something for life, an idea which we do well to lay to heart 
to-day. Leibniz states their attitude well when he says, action must accompany words, life must profit by science. And in another place he says: "As often as I learn something new I immediately consider whether something for life cannot be gotten out of it." A science which had to remain unknown to the people on account of the very language in which it was written, could not be the aim of these philosophers and hence they made a fight for the vernacular, a fight which arrayed the church and most of the learned institutions against them.

The influence of these academies, whose aim was not only to increase the stock of human knowledge but also to make all knowledge fruitful for the education of man, can hardly be overestimated. What the Italian academies have done for the Italian language has been pointed out in an earlier chapter; in a similar manner the German academies were for a time an effective bulwark against the degeneration of the German language and literature. Keller says it is in these Platonic societies and not in the universities that we must look for the birthplace of the newer German literature, and he is certainly right when he says that that fact alone would make them a noteworthy historical phenomenon.

A number of the early Italian academies had devoted themselves to natural science, and these German academies, which were often called Socratic societies, carried forward that heritage. They held that to study the works of God would do more for the glorification of His holy name than the scholastic disputations which resounded in the halls of the universities. These philosophers were seekers after truth wherever they found it and often called tbemselves Platonists or Neo-Platonists and called their science Pansophia or Natural Philosophy. Schuster says: "It is to these natural philosophers, notwithstanding their shortcomings, that we owe the great change which separates the modern world-conception from that of the middle ages." And Keller is undoubtedly right when he says, that whatever may have become of these academies (as we know, some of them became social clubs, some literary societies, etc.) it is certain that at various periods of their existence they were for many prominent men, and not least so for Comenius, places of refuge of free thought, centres of high mental and moral endeavor, and the carriers and disseminators of great ideas of reform.

When one wishes fully to realize the influence of these societies one must compare their activity with the activity of the universities. The latter, as is well known, were drying up in arid scholasticism; they held aloof from the Platonists. Men of great originality could not live within their walls. The professors at the universities looked with contempt upon every- 
thing outside of Thomas Aquinas and other accepted authorities of the church. The universities were church schools, and when we remember that their attitude was the same as that of the church, we can in some manner realize what it meant to break a lance for authors like Galileo, Grotius, Andreae, Bacon and others, as the natural philosophers did.

Petrarch called the universities seats of conceited ignorance. Leibniz held that universities were not adapted to serve the progress of science, and it is a matter of history that none of the great reformers in philosophy and in science were connected with the universities nor did they try to be. Paulsen says : "At the end of the I 7 th century the German universities had reached the lowest level they had ever had as far as the public esteem in which they were held and the influence they had on the German people were concerned. Leibniz despised a university appointment and justly hoped to find at the courts a better understanding and better support for his comprehensive plans of improving the culture of the German people. His indefatigable activity to found academies is an expression of his hopelessness as to the possibility of carrying on scientific investigations in the old universities."

To-day conditions are different in Germany. The German university is a seat of scientific investigation because it offers the greatest freedom to the scholar-it is indeed one of the freest spots on the face of the earth. Therefore we find the German scholar to be at the same time an academic teacher; among them are the philosophers, Christian Wolff, Kant, Fichte, Schelling, Hegel, Schleiermacher; the philologists Heyne, F. A. Wolf, G. Hermann, Boeckh; the scientists and mathematicians Gauss, Liebig, Helmholtz, Kirchhoff, Weierstrass, Virchow, Hertz, Roentgen; the poets, Uhland, Haller, Schiller, Rückert, Gellert; the jurists, Pufendorf, Thomasius, Savigny, Feuerbach, Niebuhr, Treitschke, and many others in all these different fields.

The same is not true in England nor in France, where the youths are not taught by the greatest scholars. The universities in these countries are not the carriers of science, this work still belongs to the great scientific academies. In England the greatest scholars were not connected with the universities, or at least did their great work ontside of them. We may mention the following: Bacon, Hobbes, Shaftesbury, Locke, Hume, Ricardo, Bentham, Gibbon, Macaulay, Carlyle, the two Mills, Grote, Spencer, Priestly, Davy, Wallaston, Young, Dalton, Faraday, Joule, Green, Boole, John and William Hunter, Jenner, Astley, Cooper, Bright, Darwin, and others.

Merz says, referring to the scientists : "Through situation 
or constitution the English universities were unable to open a field of activity for these celebrated men," whose names are identified with the greatest works in experimental science. And Paulsen says some of these men would have been impossible.in the universities.

Three Royal Societies. The great Royal societies of Europe are a development of these private academies described above. Two of them began as private societies at a time when the academies of natural philosophers still flourished, and a third, though founded later, had as its founders and chief promoters men who had belonged to, and received their training in, the earlier private academies. It is not the aim here to give a history and an evaluation of the Royal societies, for they have multiplied to such an extent, and their work has been so vast and so important that a special study is required for every branch of science. Nor is it the aim to go into the history of the numberless other academies and learned societies of Europe and America, of which there are hundreds in England alone which has over 600 such societies in all. Yet it comes within the sphere of this paper to point out briefly the relation that the earlier private academies had to the three earliest and three of the greatest of the Royal societies, namely the French, the British, and the German (Bèrlin).

The French. As early as I629, says Pellison, some men living in Paris had difficulty in finding one another and therefore resolved to meet on a certain day of the week at the house of one of their number. They were young men, one only a boy of 15 , nine in number, not very brilliant, but "all men of letters and of merit above the ordinary." At their meetings they discussed in free conversation various topics, such as the news of the day, affairs, belle lettres, and often the literary work of some member.

The members intended to keep their meetings secret, but in I634 Richelieu heard about the society and politely asked these men whether they would not like to assemble regularly under public authority. Some of the members being intimately connected with the Cardinal's enemies, there was considerable discussion, but finally the opinion prevailed that what Richelieu wished he wished seriously, and so agreeable or no, they thanked him for his kindness and accepted his offer. The king, Louis XIII, soon issued his edict and after some delay parliament registered the letters of establishment July Io, 1637 and the Academie Français, the name adopted after some deliberation by the members in session, was a fact.

The aim of the academy, being modelled after the Crusca, was to render the language capable of the greatest eloquence by cleansing it of its impurities. They wished that the French 
heroes might be sung in as noble verse as the names of the heroes of old. To accomplish this aim the academy pledged itself in its statutes to make the following books : (1) An ample dictionary; (2) An exact grammar containing a section on the ornaments of language; (3) A Rhetoric; (4) A Poetic. Only the dictionary was completed.

Progress on their work was very slow. They began with the letter $A$ and completed it in about $8 \mathrm{I} / 2$ months and then found that they had forgotten the word Academie. As the work progressed the speed slackened and it was not till I694 that "The Dictionary of the French Academy' was published.

The academy of sciences in France was founded 1666 . It began as a private society but was taken under the protection of the state by Colbert. The history of literature and of science in France cannot be written without the history of these two academies. Among its members we find most of the most brilliant French literateurs and scientists. Among them we find Corneille, Racine, Boileau, La Fontaine, Bossuet, Voltaire, Montesquieu, Buffon, Clairaut, d'Alembert, Huyghens, Mariotte, Mabillon, Rollin, Turgot, Lebrun, Mignard, Lesueur, Philippe de Champagne, Mansart, Soufflot, Chateaubriand, Victor Hugo, Lamartine, Alfred de Musset, Alfred de Vigny, Guizot, Thiers, Cousin, Monge, Berthollet, Lagrange, Laplace, Lavoissier, Fresnal, Ampère, Arago, Cuvier, Geoffroy Saint Hilaire, Cauchy, Chasles, Claude Bernard, Buffon, Jussieu, Rèamur.

The British. There were probably secret academies in England similar to those on the continent, the names of some of which are found in the correspondence of the natural philosophers; such were "Macaria," "Novo Atlantis," "Antilia," and "Utopia." It could hardly be otherwise, since in the early part of the $I 7$ th century many persecuted reformers, and especially Bohemian Brothers, fled to England for safety, and it was in London that Comenius published his "Via Lucis." Bruno is said to have gone to London to found an academy as early as 1583 . The earliest society of which we have any definite record, however, is the Academia Londinensis founded in 1645 .

According to Dr. John Wallis, one of the earliest members of this society, "several worthy persons residing in London who were inquisitive into natural and the new and experimental philosophy, agreed to meet weekly on a certain day, to discourse on such subjects." These meetings were suggested by Theodore Haak, a native of the Palatinate, and Samuel Hartlieb, of Elbing, at whose invitation Comenius had visited London, was an early member of the society.

Birch says: "Their business was, precluding affairs of state, 
and questions of theology, to consider and discuss philosophical subjects, and whatever had any connection with them, as physic, anatomy, geometry, astronomy, navigation, statics, magnetism, chemistry, mechanics, and natural experiments, with the state of these studies, as then cultivated at home and abroad."

The rules adopted in $\mathrm{r} 660$ provide for a weekly meeting; that no person shall be admitted without scrutiny except such as were of, or above, the rank of baron; that the number be 55; that 9 constitute a quorum for all business except elections when $2 \mathrm{I}$ are required; that no member be admitted on the same day he is proposed; that the officers consist of a president or director, a treasurer and a register, the first to be elected monthly, the other two yearly; that each member pay one shilling weekly to defray expenses.

In 1662 the academy was made The Royal Society and received a charter from the king. This society has largely determined the development of science in England, and its proceedings, published annually since 1665 , is a monumental record of experimental science.

Berlin. It is admitted by every one that the Berlin society owes its origin largely to the untiring zeal of Leibniz, who held to the idea of founding academies with the persistency almost of an obsession. He once said that if he were pope he would parcel out scientific studies to the different orders of the church just as he would parcel out the works of mercy. As early as 1669 he drew up a plan for an academy. His idea was to found one central society with a number of branch societies all over Germany and societies for correspondence all over the world. In his plans, we know, he always tried to get some connection with China. This reminds one very much of the plans of Andreae and Comenius.

$\mathrm{He}$ had tried to found an academy in his home city, Hanover, but failed. After a visit to Paris, he however got new enthusiasm, and in 1676 he again worked for the establishment of an academy in Germany and urges correspondence to this effect with prominent scientists such as Weigel, Schwammerdam, Leewenhoeck, Tschirnhaus, and Gericke. In 1677 he planned a "Gesellschaft von Gottesfreunden" aimed against atheism and for the study of natural philosophy. In I68 I he planned a Magnetico-Mathematical Society which was to make observations all over Germany. In Frankfort he discussed with Hiob Ludolph the plan of a royal historical society. With the marriage of Sophia Charlotte of Hanover, a princess who had grown up under his influence, in I684 to the elector prince Frederick of Brandenburg, Leibniz thought the time was propitious for the founding of an academy at Berlin. And to read 
his efforts, his failures and his delays, his hopes and his despairs is almost tragical. Whenever his efforts seemed to fail in Berlin he directed them elsewhere. In I704-5 he and Tschirnhaus had all the papers ready for the king to sign for an academy at Dresden. In I 7 I I-I 2 he had several personal conferences and exchanged many letters with the czar concerning an academy at St. Petersburg. In I7/2-I4 he was in Vienna trying to found an academy there. But all his efforts were for the time being in vain.

The "Stiftungsbrief" for the Berlin academy was issued as early as July II, I 700, just as it had been drawn up by Leibniz. It outlines the field of work in very general terms, probably purposely so; it gives to the society three chief aims : "Das Evangelisch-Civilisatorische," "das Naturwissenschaftlich-Praktische," and "das Deutsch Nationale" as Harnack puts it. Leibniz was made president and was to receive 1,000 Thaler as salary and reimbursment for correspondence and travelling expenses, but he never received more than 600, and even that seemed to be given grudgingly. There were several great obstacles to be overcome which brought the society several times to the verge of ruin. First, there was no money; secondly, King Frederic had lost faith in Leibniz because there was jealous opposition to the latter at the court. And so we find that when after a long and tedious struggle the academy was inaugurated on Jan. I9, I 7 I I, it became known that an honorary president had been appointed who was also director, and Leibniz was only ordinary president. Thus after all these years of unrequited toil Leibniz was practically set aside and others were to reap the fruits of his labor.

On Nov. 14, I 7 16, Leibniz died lonely and forlorn, suspected by the House of Brandenburg and neglected by the House of Hanover. All his great plans seemed to shatter. But, Harnack says, what he created in the domain of mind has remained imperishable; nearly all his great projects have been gradually realized in the course of time. He did not only scatter seeds into the future, but he gave form to, and built the house for, scientific work for the future.

In I 740, with the accession of Frederic the Great, the academy was reorganized and received new impetus and ever since it has stood at the front of scientific activity in Germany. Harnack says: When one considers the discoveries and works of the mathematicians, physicists, the chemists, the astronomers, the botanists and the anatomists during the 40 years (1740I780) one can say that this academy stood at the very apex of scientific activity and was not surpassed by any other. $\mathrm{He}$ says, the German enlightenment of the i 8 th century was largely due to the academy, and it was first through Leibniz and then 
through the enlightenment that Germany entered upon world literature.

Amongst its members we find the brightest lights of science in Germany-such as Leibniz, Euler, Lagrange, Lambert, Lieberkühn, Achard, Gleditsch, the Humboldts, Helmholtz. and others. In I8II, when the Berlin university was founded, the academy was affiliated with the university, but even to-day it is a greater honor to be a member of the academy than to be a professor in the university-it is the greatest honor that can be bestowed upon a German man of science.

The Berlin society did not begin as a private academy, but Leibniz and a number of the early members had in earlier years been connected with private academies in other parts of Europe. Leibniz, himself, confessed that Nürnberg first introduced him to chemical studies and that here he first learned what proved to be so useful to him in later years, namely, caution. The later royal societies in Europe were all more or less modelled after the first ones, and so we may say that, indirectly at least, all the European royal societies are an outgrowth and a development of the secret academies of natural philosophers of earlier times.

\section{SUMmary.}

In conclusion the following points may be noted. Points 5I I refer chiefly to academies of the Renaissance and later.

I. Such associations of scholars have existed from early times, probably continuously, till the present; and before the moderu university they were, and in some countries even now are, the great carriers of science.

2. These learned societies fostered open-mindedness toward truth which was in danger of being engulfed by ignorance and bigotry. They contributed largely toward keeping the idea of finality out of science. The men that belonged to them realized that the present is only a link between the past and the future, that science ever advances without reaching finality.

3. In various periods of their development the history of these academies constitutes the history of science or of literature, or of both, in the countries in which they flourished.

4. Those universities which are among the carriers of science to-day have adopted the principle of freedom which prevailed in the academies, because only by doing so could they attract the best scholars of their day.

5. The academies of the Renaissance and later cultivated the vernacular, and in northern Europe they were the birthplace of the newer German literature and brought about the enlightenment. 
6. Much of the work of the great reformers in science and religion might not have borne fruit had it not been for these academies. They did not only disseminate the writings of these great men, but they were to them a haven of refuge during times of severe persecution.

7. They held that education must touch life, -a principle which to-day needs awakening in our education from the kinddergarten to the university.

8. As to the principle: Education is not for the few alone. these academies were the predecessors of Pestalozzi.

9. They advocated religious toleration-an idea which we to-day, even, have not yet developed to maturity.

Io. They were the forerunners of the great royal societies of to-day.

II. In I643 the Great Elector of Brandenburg became a member of the "Fruchtbringende Gesellschaft," and several other princes of the same house were members. After the founding of the university of Halle the princes of the house of Hohenzollern were educated there in the liberal ideas advocated by the academies and represented there by Thomasius, a disciple of Grotius, and the first man who lectured in German in a German university. What all this means for education and for religion the culture history of Germany amply shows.

\section{BIBLIOGRAPHY.}

This bibliography is not intended to be complete, but rather to include the chief works consulted in this study. The book by Jos. Reber, and the one by Guhrauer are out of print and could not be found in this country. If a reader of this article knows where they can be bought or borrowed, Dr. L,ouis N. Wilson, Librarian of Clark University, will be thankful for the information.

I. ARNOLD, MATSHEW. Essay on the Literary Influence of Academies. in Essays in Criticism. Boston, r865. pp. 506.

2. BAFR, K. E. von. Reden. (Chap. III, Blicke auf d. Entwickelung der Wissenschaft. pp. 75-r6o.) St. Petersburg, 1864. pp. 296.

3. Barthold, F. W. Geschichte der Fruchtbringenden Gesel1schaft. Berlin, 1848 . pp. 328 .

4. BIRch, Thos. The History of the Royal Society of London. London, 7756 . 4 vols.

5. DrELs, H. Ueber die ältesten Philosophenschulen der Griechen. In Philosophische Aufsätze, Ed. Zeller gewidmet. Leipzig, 1887. Pp. 24I-260.

6. DOREN, ALFRED. Entwickelung u. Organisation der Florentiner Zünfte in I3. u. 14. Jahrhundert.-Staats-u. Sozial wissenschaftliche Forschungen, herausg. von G. Schmoller, Bd. XV (I897), Heft 3. 
7. D'ELVERT. Von den Literaten Gesellschaften in Böhmen und Mähren. Schriften der hist. statist. Sektion der S. S. mährish -schles. Gesellschf. d. Wiss. Heft II. Brünn, I853.

8. Gindel, $x$, A. Die dogmatischen Ansichten der Böhmischen Brüder. Sitzungsber. d. Akad. d. Wissenschaften zu Prag. Vol. XIII.

9. GormarN, E. Culturentwickelung Süditaliens in Einzeldarstellung. Breslau, r886. pp. 600.

Io. GuhraUER. Joachim Jungius u. sein Zeitalter. Stuttgart u. Tübingen, 1850 .

II. HaRnack, A. Geschichte der Preussischen Akademie der Wissenschaften. Berlin, Igor. 4 vols.

I2. KelLER, L. Die Akademien der Platoniker im Alterthum. Mon. d. Com. Gesell., r898, VII, 269-293.

13. - Die Anfänge d. Renaissance u. d. Kultusgesellschaften des Humanismus in 13. u. r4. Jahrh. Mon. d. Com.Gesell., I903, XII, 76-103.

I4. - Die Ánfänge der Reformation und die Ketzerschulen. Mon. d. Com. Gesel1., 1896, V, 249-309.

15. - Die Böhmischen Brider und ihre Vorläufer. Mon. d. Com. Gesell., I894, Vol. III, I7I-209.

16. - Leibniz u. d. Deutschen Sozietäten des 17. Jahrh. Mon. d. Com. Gesell., I903, XII, I4I-156.

I7. - Comenius u. d. Akademien der Naturphilosophen des 17. Jahrhunderts. Mon. d. Com. Gesell., IV, I895. pp. 1-28, 69-96, I33-184.

I7a. - Die Römische Akademie u. a. altchristlichen Katakomben im Zeitalter der Renaissance. Mon. d. Com. Gesell., I899, VIII, 63-I00. (See also his book on this subject. Berlin, 1899.)

18. Kvacala. Die Spanhein-Conferenz in Berlin. Zur Geschichte des Ursprungs der Berliner Akad. der Wissenschaften. Mon. d. Com. Gesell., r900, IX, 22-43.

19. Marcou, Jules. De la Science en France; Chap. 2, L'Académie des Sciences de 1'Institut Imperial de France. Paris, 1869. pp. IOT-208.

20. MAURy, M. A. History of Old Academy of Science in France.

2I. MERZ, J. T. Hist. of European Thought in the rgth Century. London, 1896.2 vols.

22. MeSNARd, PaUr. Histoire de l'Académie Française jusqu'a 1830. Paris, 1859.

23. MÜLLER, J. Die Gemeinde-Verfassung der Böhmischen Brüder. Mon. d. Com. Gesell., V, I896. pp. I40-163.

24. PAULSEN, F. Die Deutschen Universitäten u. das Universitätsstudium. Berlin, IgO2. pp. 575 .

25. Peicisson, Fontanier P. Histoire de L'Académie Française, depuis son établissement jusqu'a 1652. In Archives Curieuses de L'Histoire de France, by Cimber \& Danjou, Vol. VI, I838. pp. $7 \mathrm{I}-2 \mathrm{I} 4$.

25a. Peirlisson ET D'OLivet. Histoire de L'Academie Française. Paris, 1858, I, pp. 526: II, pp. 574.

26. REBER, Jos. Johann Amos Comenius u. seine Beziehungen zu den Sprachgesellschaften. Leipzig, I894.

27. REUMONT, ALFRED VON. Beiträge zur Italienschen Geschichte. Berlin, 1857, Vol. VI. pp. I4I-239. (Chap. entitled: Zur Geschichte der Akademie der Crusca.)

28. SchurTz, H. Die Bestrebungen der Sprachgesellschaften des 17. Jahrhunderts. Göttingen, 1888. pp. I58. 
29. Schut,TzE, Fritz. G. Gemisthos Plethon. Jena, r874. pp. 320. (Vol. I, of Geschichte der Philosophie der Renaissance.)

3o. Schuster, GeorG. Die Geheimen Gesellschaften Verbindungen und Orden. Leipzig. 1904. pp. $55^{8}$.

3r. Srevering. Geschichte von Florenz. Hamburg, 1847. pp. 176. (Publ. anonymously. Hist. of Florentine Acad. in Appendix.)

32. Simon, JUles. The Centennial of the Institute of France. Smithsonian Report, I995. pp. 713-727.

33. SpRat, Tho. The History of the Royal Society of London, I734. pp. 438 , 4 th ed. (First ed. I667.)

(It covers only the very early years of the society.)

34. Thomson, THos. History of the Royal Society to End of $18 \mathrm{th}$ Century. I Iondon, r812. pp. 552. (Contains charter and list of members.)

35. USENER, HERM. Organisation der Wissenschaftlichen Arbeit, etc. Preuss. Jahrb. I884, Bd. 53, pp. I-25.

36. VIILARI, P. Iife and Times of Savonarola. New York, 1888. pp. 792.

37. VINCENT, L. H. The French Academy. Cambridge, rgor. pp. I59.

38. WELD, C. $R$. History of the Royal Society. London, 1848,2 vols. (Contains statutes of society.)

39. WrLAMOWITZ-MOELLENDORF, U. $v$. Die rechtliche Stellung der Philosophenschulen. Philologische Untersuchungen, IV, pp. 263-29I.

40. Encyclopedia Britt. Ct. "Royal Society" and "Academy."

4I. Monatshefte der Comenius Gesellschaft, from I8gI to date. 